\title{
Modified Tin Oxide Based Bioelectrode for Reagentless Detection of Uric Acid
}

\author{
Kashima Arora ${ }^{1}$, Monika Tomar ${ }^{2}$ and Vinay Gupta ${ }^{1 *}$
}

${ }^{1}$ Department of Physics and Astrophysics, University of Delhi, Delhi, India

${ }^{2}$ Department of Physics, Miranda House, University of Delhi, Delhi, India

\begin{abstract}
A reagentless uric acid biosensor has been realized using Copper implanted tin oxide thin film $\left(\mathrm{Cu}: \mathrm{SnO}_{2}\right)$ based matrix. The biosensing characteristics of implanted matrix have been studied using the electrochemical impedance spectroscopy and cyclic voltammetry. The prepared matrix $\left(\mathrm{Cu}: \mathrm{SnO}_{2}\right)$, because of the presence of $\mathrm{Cu}$, possess redox properties so that the electron transfer from enzyme to the electrode could be accomplished without using any external mediator in the electrolyte. The developed uric acid biosensor exhibits a high sensitivity of about $0.93 \mathrm{~mA} /$ $\mathrm{mM}$ and a linear variation in current response over a concentration range from 0.05 to $1.0 \mathrm{mM}$ of uric acid besides high shelf life ( $\sim 20$ weeks). The Michaelis-Menten kinetic parameter $\left(K_{m}\right)$ is found to be relatively very low $(0.12 \mathrm{mM})$, which indicates the high affinity of the fabricated bioelectrode towards the uric acid (analyte). The results highlight the importance of implanted $\mathrm{Cu}: \mathrm{SnO}_{2}$ thin film as an attractive matrix for the realization of reagentless biosensors towards uric acid.
\end{abstract}

Keywords: Reagentless uric acid biosensor; RF sputtering; $\mathrm{Cu}$ implanted $\mathrm{SnO}_{2}$

\section{Introduction}

Uric acid is present in number of biological fluids including urine and blood serum and is associated with the presence of diseases such as gout, hyperuricemia, cholesterol, arthritis, renal, neurological, kidney diseases etc. Thus, efficient detection of uric acid in human blood is of great interest to the researchers. Many reports are available on the detection of uric acid [1,2], but the presence of external mediator in the electrolyte hinders its usage for implantable biosensor. Limited work has been carried out on the development of reagentless uric acid biosensors, where no external mediating element is needed. Table 1 summarizes the work carried out on uric acid biosensors by various workers using different matrices. Various matrices have been utilized for the detection of uric acid such as APTES Bis sulfosuccinimide/ITO [3], gold electrode/polystyrene [4], carbon felt based $\mathrm{H}_{2} \mathrm{O}_{2}$ [5], poly N-isopropyl acrylamide MWCNT-Ch/poly(amidoamine)/DNA/gold electrode [6], Polyaniline [7], screen printed electrode [8] and so on. However, the low sensitivity and poor shelf life of the biosensors are major concern. Metal oxide thin film-based bioelectrodes are shown to be advantageous. Tin oxide $\left(\mathrm{SnO}_{2}\right)$, a wide band gap semiconductor $\left(\mathrm{E}_{\mathrm{g}}=3.87 \mathrm{eV}\right)$, has multifunctional properties for broad range of applications including transparent electronics, gas sensors, acoustic devices, UV photo detectors, etc.

Recently $\mathrm{SnO}_{2}$ is being explored for biosensing applications owing to its excellent charge transfer capability, good biocompatibility, low cost, abundance in nature etc. [9]. However, the non-redox property of $\mathrm{SnO}_{2}$ demands an external mediator in the electrolyte, which hinders its application for realizing an integrated biosensor. Few attempts have been made towards tailoring the properties of metal oxides by introducing suitable metal dopants [10]. The metal ions having multiple valence states such as $\mathrm{Fe}, \mathrm{Cu}, \mathrm{Mn}, \mathrm{V}$ etc. can be incorporated to induce redox properties in the host metal oxide matrix [11]. However, most of the reports on doped metal oxide matrix are using chemical route which lead to the preparation of bioelectrodes with poor stability [12]. The rapid decay in the response of these bioelectrodes with time may be due to poor incorporation of metal dopants at the lattice sites of host oxide matrix and poor quality of deposited films. Implantation is an effective method to incorporate the foreign elements in the metal oxides and to tailor its properties. Few reports are available on incorporating redox species into the $\mathrm{ZnO}$ matrix using ion implantation of $\mathrm{Fe}$ for reagentless detection of glucose [13]. Surprisingly, no efforts are being made to modify the electronic properties of $\mathrm{SnO}_{2}$ by implanting it with suitable metals that have multiple oxidation states especially for detection of uric acid. Amongst different metals, copper $(\mathrm{Cu})$ has multi-electron oxidation states and is attractive due to natural abundance, low cost, non-toxic and good electrochemical activity $[6,14]$. The impantation of $\mathrm{Cu}$ in $\mathrm{SnO}_{2}$ may induce the redox property besides enhancing the electron transfer property for possible biosensing application.

In this paper, the $\mathrm{SnO}_{2}$ thin films were prepared by $\mathrm{RF}$ sputtering technique and $\mathrm{Cu}$ implanted $\mathrm{SnO}_{2}$ matrix has been utilized for development of reagentless uric acid biosensor. The biosensor is found to be exhibiting excellent response characteristics important for use in implantable biosensor chip.

\section{Materials and Methods}

\section{Materials}

Uric acid (99.99\% pure), Uricase (1 $\mathrm{mg} / \mathrm{mL})$ horseradish peroxidase (HRP) and o-dianisidine dye were procured from SigmaAldrich. Sodium phosphate monobasic anhydrous and sodium phosphate dibasic dihydrate (analytical reagent grade) were obtained from Sisco Chemical, India. All the chemicals were used without any further purification. Deionized water having a high resistivity of 18.2

*Corresponding author: Vinay Gupta, Department of Physics and Astrophysics University of Delhi, Delhi 110007, India, Tel: 0112700 6900; E-mail: vgupta@physics.du.ac.in

Received August 10, 2017; Accepted August 23, 2017; Published August 30 2017

Citation: Arora K, Tomar M, Gupta V (2017) Modified Tin Oxide Based Bioelectrode for Reagentless Detection of Uric Acid. J Biosens Bioelectron 8: 246. doi: 10.4172/2155-6210.1000246

Copyright: ( 2017 Arora K, et al. This is an open-access article distributed under the terms of the Creative Commons Attribution License, which permits unrestricted use, distribution, and reproduction in any medium, provided the original author and source are credited. 


\begin{tabular}{|c|c|c|c|c|c|c|c|}
\hline S.No. & Material & Range & Sensitivity & Response time & $\mathrm{Km}$ & Detection limit & Ref. \\
\hline 1. & SAM of APTES Bis sulfosuccinimide/ITO & $0.05-0.58 \mathrm{mM}$ & $39.35 \mu \mathrm{A}_{\mathrm{mm}}-1$ & $50 \mathrm{~s}$ & - & $0.037 \mathrm{mM}$ & 3 \\
\hline 2. & Gold electrode/polystyr ene & $5-105 \mu \mathrm{M}$ & & Within $1 \mathrm{~min}$ & - & & 4 \\
\hline 3. & $\mathrm{ZnO}$ nanowires & $1-1000 \mu \mathrm{M}$ & $32 \mathrm{mV} /$ decade & 9s & - & $1 \mu \mathrm{M}$ & 20 \\
\hline 4. & Carbon felt based $\mathrm{H}_{2} \mathrm{O}_{2}$ & $0.3-20 \mu \mathrm{M}$ & $0.25 \mu \mathrm{A} \mathrm{mM}^{-1}$ & & - & $0.18 \mu \mathrm{M}$ & 5 \\
\hline 5. & $\begin{array}{l}\text { MWCNT- Ch/poly (amidoa mine)/DNA/ } \\
\text { gold electrode }\end{array}$ & $0.5-100 \mu \mathrm{M}$ & $43.9 \mathrm{nA} / \mathrm{mM}$ & $5 s$ & - & $0.07 \mu \mathrm{M}$ & 6 \\
\hline 6. & Polyaniline & $0.01-0.6 \mathrm{mM}$ & $47.2 \mathrm{~mA} / \mathrm{mM}$ & $60 s$ & $5.1 \times 10^{-3} \mathrm{mM} / \mathrm{L}$ & $0.01 \mathrm{mM}$ & 7 \\
\hline 7. & Polyurethane hydrogel & $0-2 \mathrm{mM}$ & & $80-100 s$ & & & 21 \\
\hline 8. & Screen printed electrode & $2-40 \mu \mathrm{M}$ & $3.05 \mu \mathrm{A} \mu \mathrm{M}^{-1}$ & & & $0.42 \mu \mathrm{M}$ & 8 \\
\hline 9. & Poly(o- aminophenol) C paste electrode & Upto $10^{-4} \mathrm{M}$ & $5 \mu \mathrm{A}$ & $37 s$ & & $3 \times 10^{-6} \mathrm{M}$ & 22 \\
\hline 10. & MWCNT/Au nps. & $0.01-0.8 \mathrm{mM}$ & $0.44 \mathrm{~mA} \mathrm{mM}^{-1}$ & $7 \mathrm{~s}$ & $0.5 \mathrm{mM}$ & $0.01 \mathrm{mM}$ & 23 \\
\hline 11. & 3 amino5- mercapto-124 triazole/GC & $40 \mathrm{nM}-0.1 \mathrm{mM}$ & & $50 \mathrm{~s}$ & & $0.52 \mathrm{nM}$ & 24 \\
\hline 12. & Epoxy resin biocomposite & $0.025-0.1 \mathrm{mM}$ & & $12 \mathrm{~s}$ & $0.17 \mathrm{mM}$ & $4.25 \mu \mathrm{g} / \mathrm{mL}$ & 25 \\
\hline 13. & Ir-C electrode & $0.1-0.8 \mathrm{mM}$ & $16.60 \mu \mathrm{M} / \mathrm{mM}$ & $<45 \mathrm{~s}$ & & $0.01 \mathrm{mM}$ & 26 \\
\hline 14. & & $0.005-0.8 \mathrm{mM}$ & & $4 \mathrm{~s}$ & $0.058 \mathrm{mM}$ & $5 \mu \mathrm{M}$ & 27 \\
\hline 15. & Mercaptoethylpy razine/Au & $5-150 \mu \mathrm{M}$ & $3.4 \pm 0.08 \mathrm{nA}_{\mathrm{cm}^{-2}}{ }_{\mu \mathrm{M}}^{-1}$ & $80-100 s$ & $290 \mu \mathrm{M}$ & $2 \mu \mathrm{M}$ & 28 \\
\hline
\end{tabular}

Table 1: Brief summary of the important reports on uric acid biosensors

$\mathrm{M} \Omega \mathrm{cm}$ was used for the preparation of aqueous solutions. Different concentrations of uric acid solution $(0.05-1.0 \mathrm{mM})$ and solution of o-dianisidine (1\%) dye were freshly prepared in de-ionized water.

\section{$\mathrm{Cu}$ implanted $\mathrm{SnO}_{2}$ thin film based electrode}

A $100 \mathrm{~nm}$ thin Pt layer was deposited on the surface of corning glass slide over an area of $2 \mathrm{~cm} \times 1 \mathrm{~cm}$ by RF sputtering technique using a 3 inch diameter metal Pt target (99.99\% pure) under 100\% Ar gas ambient and a power of $100 \mathrm{~W}$. A buffer layer $(\sim 10 \mathrm{~nm})$ of titanium (Ti) was sputter coated prior to Pt deposition under the same growth condition onto the glass slide using a Ti target (99.99\% pure) to improve the adhesion of $\mathrm{Pt}$ on the glass slide. $\mathrm{SnO}_{2}$ thin film was deposited on to $\mathrm{Pt} / \mathrm{Ti}$ coated Corning glass slide using RF magnetron sputtering technique on an area of $1 \mathrm{~cm} \times 1 \mathrm{~cm}$ while the remaining $1 \mathrm{~cm} \times 1 \mathrm{~cm}$ area was protected using shadow mask for electrical connections. A 2 inch diameter metallic tin target $(99.999 \%$ pure) was sputtered in a reactive gas mixture $\left(70 \% \mathrm{Ar}\right.$ and $30 \% \mathrm{O}_{2}$ ) at an rf power of $30 \mathrm{~W}$ and sputtering pressure of 20 mTorr. The thickness of $\mathrm{SnO}_{2}$ thin film was maintained at $180 \mathrm{~nm}$. Subsequently, Copper $(\mathrm{Cu})$ was implanted in as-grown $\mathrm{SnO}_{2}$ thin film at room temperature at low energy (15 keV) to a fluence of $10^{15}$ and $10^{16} \mathrm{~cm}^{-2}$. The ion implantation was carried out on low energy ion implanter $-150 \mathrm{kV}$ accelerator at the Australian National University, Australia. The biosensor electrode for detection of uric acid has been prepared on $\mathrm{Cu}$ implanted $\mathrm{SnO}_{2}$ matrix and the fabrication steps are shown schematically in Figure 1.

Preparation of PBS solution: Phosphate Buffer Saline (PBS) solution $(50 \mathrm{mM})$ of $\mathrm{pH} 7$ was prepared by adjusting the proportion of monobasic sodium phosphate solution and dibasic sodium phosphate solution and then adding $0.9 \% \mathrm{NaCl}$ to the solution. PBS containing $\left[\mathrm{Fe}(\mathrm{CN})_{6}\right]^{3-/ 4}$ solution was prepared by adding $5 \mathrm{mM}$ potassium ferrocyanide $\left[\mathrm{K}_{4} \mathrm{Fe}(\mathrm{CN})_{6}\right]$ and potassium ferricyanide $\left[\mathrm{K}_{3} \mathrm{Fe}(\mathrm{CN})_{6}\right]$ in the prepared PBS solution for electrochemical impedance spectroscopy (EIS) measurements. Cyclic voltammetry (CV) measurements were carried out in PBS solution without the addition of any external mediator such as ferro/ferri cyanide.

Preparation of Bioelectrode: Immobilization of Uricase on $\mathrm{Cu}$ implanted $\mathrm{SnO}_{2}$ matrix: The fabrication process of bioelectrode (Uricase/Cu:SnO $/ 2 / \mathrm{Pt} /$ glass) is schematically shown in Figure 1. In order to prepare the bioelectrode, $\mathrm{Cu}$ implanted $\mathrm{SnO}_{2}$ matrix was hydrolysed by immersing the electrode $\left(\mathrm{Cu}: \mathrm{SnO}_{2} / \mathrm{Pt} / \mathrm{Ti} /\right.$ glass $)$ in a solution of $\mathrm{H}_{2} \mathrm{O}_{2} /$ $\mathrm{NH}_{4} \mathrm{OH} / \mathrm{H}_{2} \mathrm{O}(1: 1: 5, \mathrm{v} / \mathrm{v})$ for $30 \mathrm{~min}$ at $80{ }^{\circ} \mathrm{C}$. The hydrolyzed matrix was immersed in $1 \%(\mathrm{v} / \mathrm{v})$ solution of APTES in toluene overnight at room temperature for silanization. After the coupling reaction, the electrodes were rinsed with toluene and water to remove the loosely bound silanes from the surface of implanted matrix. The modified electrodes after silanization were dried under a stream of nitrogen. Uricase was covalently attached to the functionalized electrodes using EDC/NHS chemistry. The amount of enzyme used for immobilization was optimized and maximum binding was observed when $5 \mu$ of uricase solution was diluted to $30 \mu \mathrm{l}$ in distilled water containing 0.4 M EDC and 0.1 M NHS. The enzyme solution was poured onto $1 \mathrm{~cm}^{2}$ area of the electrode having functionalized $\mathrm{Cu}: \mathrm{SnO}_{2}$ matrix and kept for approximately $4 \mathrm{~h}$ in a humid chamber at room temperature for the binding of uricase using cross linkers. The bioelectrode was dried under nitrogen flow and stored at $4{ }^{\circ} \mathrm{C}$ when not in use.

\section{Characterization techniques}

The structural and optical properties of the developed $\mathrm{Cu}$ implanted $\mathrm{SnO}_{2}$ matrix were studied using an X-ray diffractometer (Bruker D8 Discover) and a double beam Uv-visible spectrophotometer (Perkin Elmer, Lambda 25-35-45) respectively. Implantation of $\mathrm{Cu}$ into $\mathrm{SnO}_{2}$ matrix is confirmed by energy-dispersive $\mathrm{X}$-ray spectroscopy (EDX) analysis. Modification of surface morphology before and after immobilization of the uricase were investigated using an atomic force microscope (Veeco DICP2) in non-contact mode, a scanning electron microscope and a fourier transform infrared spectrophotometer (Perkin Elmer (Model Spectrum BX). Micro images obtained from AFM were analyzed by SPM Lab Analysis software. Electrochemical measurements were carried out on a potentiostat/galvanostat/ZRA (Gamry reference using a conventional three-electrode electrochemical cell with $\mathrm{Ag} / \mathrm{AgCl}$ as reference electrode, platinum (Pt) foil as counter electrode and uricase $/ \mathrm{Cu}: \mathrm{SnO}_{2} / \mathrm{Pt} / \mathrm{Ti} /$ glass as working electrode. The enzyme activity of bio-electrode was studied using UV-visible spectrophotometer (Perkin Elmer, Lambda 35). The thickness of deposited thin film was determined using surface profiler (Dektak $150 \mathrm{~A})$. PBS solution $(10 \mathrm{ml}, 50 \mathrm{mM}, 0.9 \% \mathrm{NaCl})$ without any mediating species was used as electrolyte.

\section{Results and Discussion}

\section{X-Ray Diffraction (XRD) studies}

The XRD studies of as-deposited $\mathrm{SnO}_{2}$ films shows the growth of amorphous film, which became polycrystalline after a post deposition 


\section{FLOWCHART}

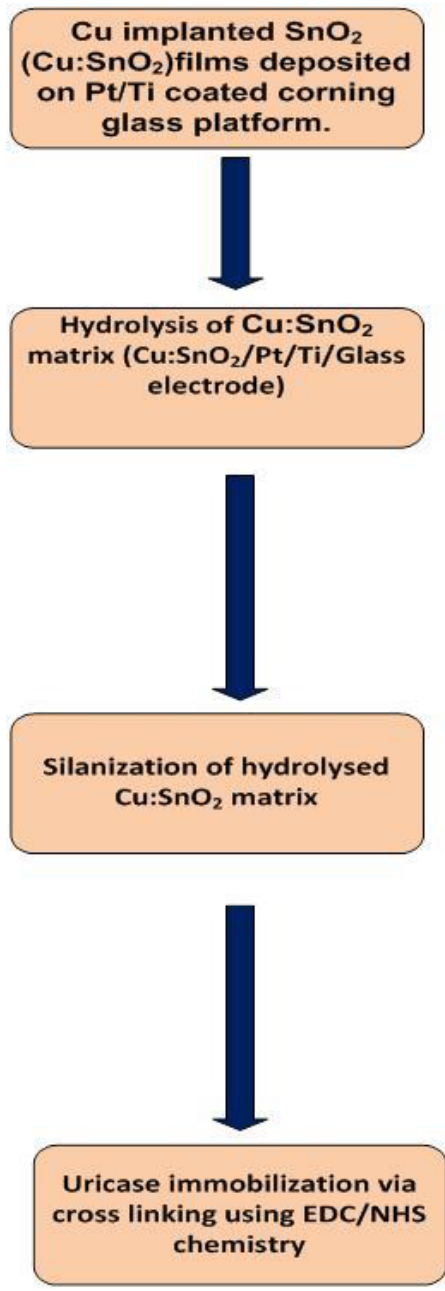

\section{SCHEMATIC}
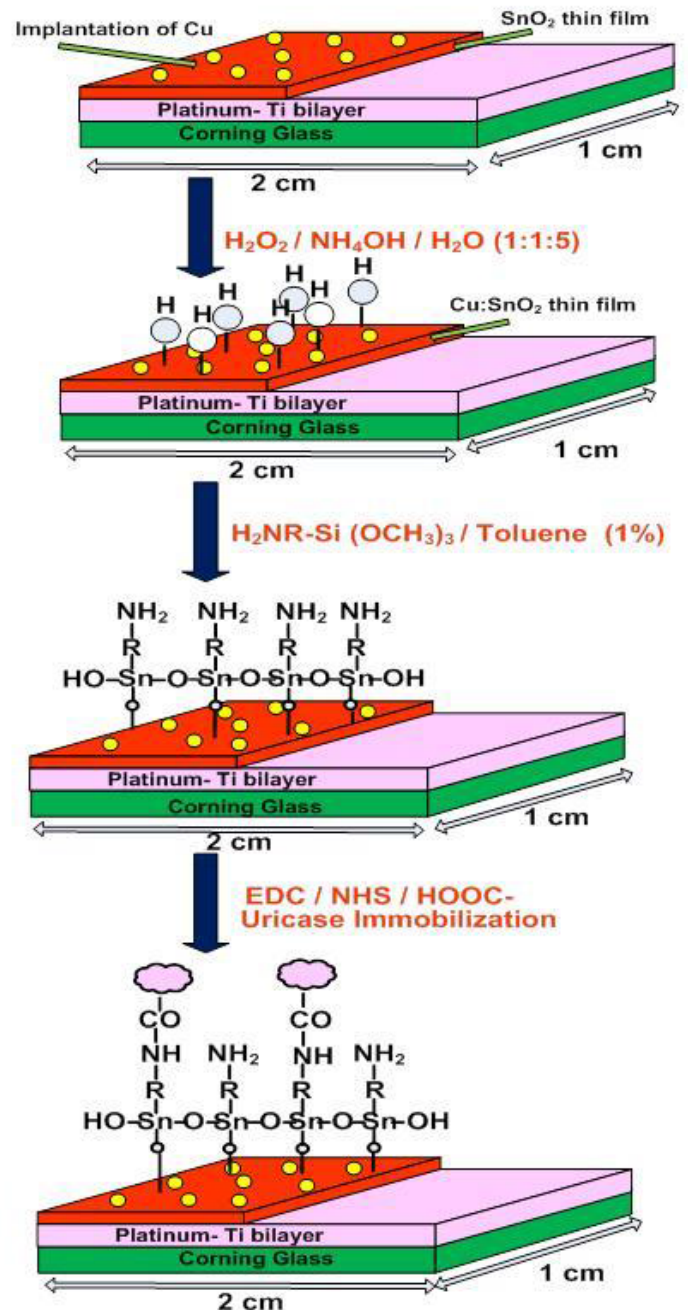

${ }^{\star} N O T E: ~ R H_{2}=-\mathrm{CH}_{2}-\mathrm{CH}_{2}-\mathrm{CH}_{2}-\mathrm{NH}-\mathrm{CH}_{2}-\mathrm{CH}_{2}-\mathrm{NH}_{2}$

$\widetilde{O}=$ Uricase

Figure 1: Schematic of Immobilization of uricase on $\mathrm{Cu}$ implanted $\mathrm{SnO}_{2}$ matrix via $\mathrm{EDC} / \mathrm{NHS}$ chemistry.

annealing treatment at $300^{\circ} \mathrm{C}$ in air for $2 \mathrm{~h}$. The XRD spectrum for the annealed $\mathrm{SnO}$, film deposited on glass slide is shown in Supplementary Figure 1a. Well defined reflection peaks corresponding to (110), (101), (200) and (211) planes of rutile $\mathrm{SnO}_{2}$ were observed in the XRD pattern [15], indicating that the annealed $\mathrm{SnO}_{2}$ thin film is polycrystalline. The average crystallite size of the $\mathrm{SnO}_{2}$ film was calculated from the dominant (101) XRD peak using the Debye Scherrer's formula and is found to be about $9 \mathrm{~nm}$.

XRD patterns of the $\mathrm{Cu}$ implanted $\mathrm{SnO}_{2}$ films are shown in Supplementary Figure $1 \mathrm{~b}$ and $1 \mathrm{c}$. It may be seen from Figure 2 that no peak corresponding to $\mathrm{Cu}$ was observed in the XRD pattern of $\mathrm{Cu}$ implanted $\mathrm{SnO}_{2}$ thin films. However, $\mathrm{SnO}_{2}$ film became preferred oriented along (101) direction with implantation of $\mathrm{Cu}$ (Supplementary Figure 1). The crystallinity of $\mathrm{SnO}_{2}$ thin film improves with increasing the fluence of $\mathrm{Cu}$ implantation. The observed improvement may be associated with the recrystalization of the $\mathrm{SnO}_{2}$ film surface on ion implantation and substitution of $\mathrm{Cu}$ ions at its lattice sites
(Supplementary Figure 1). The crystallite size of implanted samples is found to be almost same $(10 \mathrm{~nm})$ as that of pure $\mathrm{SnO}_{2}$ film.

\section{Energy-dispersive $\mathrm{X}$-ray spectroscopy (EDX) analysis of $\mathrm{Cu}$ implanted $\mathrm{SnO}_{2}$ matrix}

EDX spectra of bare $\mathrm{SnO}_{2}$ and $\mathrm{Cu}$ implanted $\left(10^{16} \mathrm{~cm}^{-2}\right.$ fluence $)$ $\mathrm{SnO}_{2}$ films deposited on $\mathrm{Pt}$ coated $\mathrm{Si}$ wafer are shown in Figure 2. The presence of both $\mathrm{Sn}$ and $\mathrm{O}$ can be easily seen in the EDX spectra along with the weak peaks corresponding to $\mathrm{Pt}$ and $\mathrm{Si}$, which are due to the underneath $\mathrm{Pt}$ electrode and $\mathrm{Si}$ wafer, respectively. The additional peaks observed corresponding to the $\mathrm{Cu}$ in the EDX spectra of $\mathrm{Cu}$ implanted $\mathrm{SnO}_{2}$ film $\left(\mathrm{Cu}: \mathrm{SnO}_{2}\right)$, clearly confirm the presence of $\mathrm{Cu}$ in the implanted $\mathrm{SnO}_{2}$ matrix.

\section{Electrochemical studies of electrodes}

Cyclic voltammetry: The cyclic voltammograms (CVs) of $\mathrm{SnO}_{2} /$ $\mathrm{Pt} /$ glass and $\mathrm{Cu}: \mathrm{SnO}_{2} / \mathrm{Pt} /$ glass electrodes were recorded in the PBS 
Citation: Arora K, Tomar M, Gupta V (2017) Modified Tin Oxide Based Bioelectrode for Reagentless Detection of Uric Acid. J Biosens Bioelectron 8: 246. doi: $10.4172 / 2155-6210.1000246$

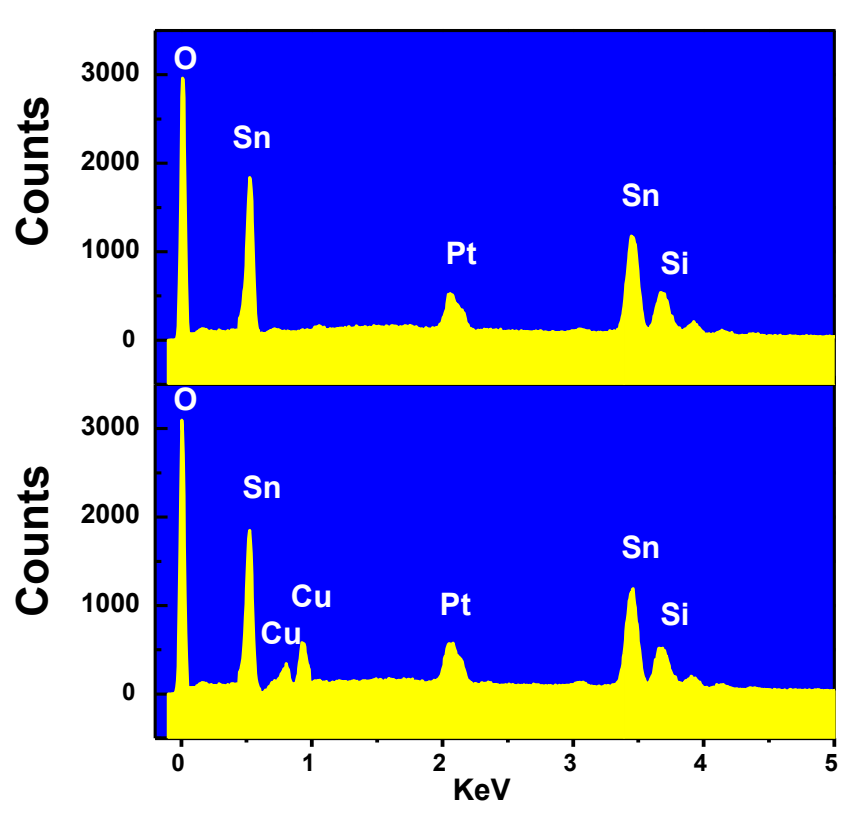

Figure 2: EDX spectra of the (a) bare $\mathrm{SnO}_{2}$ film and (b) $\mathrm{Cu}$ implanted $\mathrm{SnO}_{2}$ film at a fluence of $10^{16} \mathrm{~cm}^{-2}$.

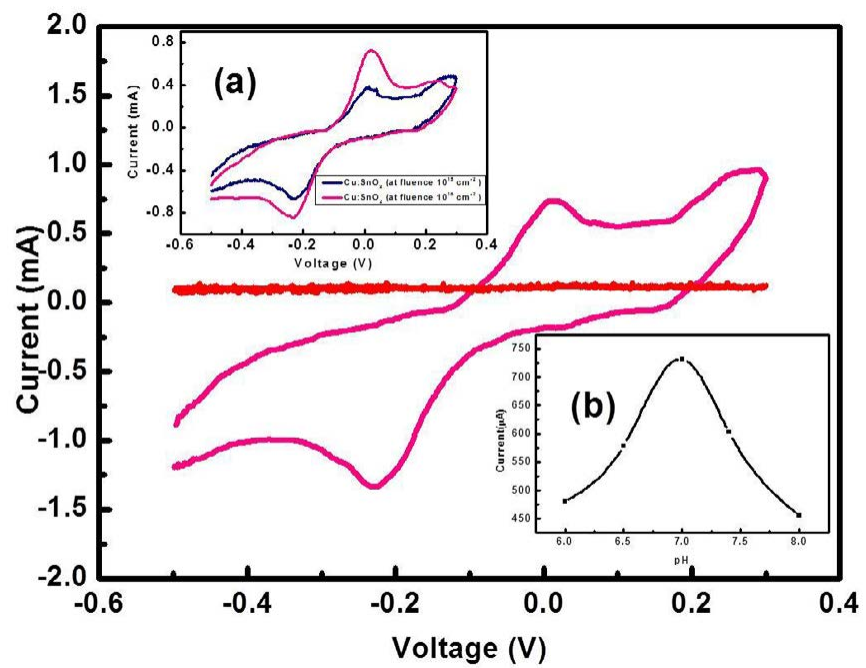

Figure 3: Cyclic voltammograms of $\mathrm{SnO}_{2} / \mathrm{Pt} /$ glass and $\mathrm{Cu}: \mathrm{SnO}_{2} / \mathrm{Pt} /$ glass electrodes in PBS buffer. Insets (a) and (b) shows the Cyclic voltammograms of $\mathrm{Cu}$ implanted $\mathrm{SnO}_{2}$ at fluences of $10^{15}$ and $10^{16} \mathrm{~cm}^{-2}$ and variation of peak oxidation current $\left(\mathrm{I}_{\mathrm{pa}}\right)$ with $\mathrm{pH}$ for the bioelectrode implanted with $10^{16} \mathrm{Cu} /$ $\mathrm{cm}^{-2}$, respectively.

electrolyte without any redox speciclearly seen that no redox peak is observed in the $\mathrm{CV}$ spectra for $\mathrm{SnO}_{2} / \mathrm{Pt} / \mathrm{Ti} /$ glass electrode in $\mathrm{PBS}$ solution in the entire measured range of voltage $(-0.5 \mathrm{~V}-0.3 \mathrm{~V})$ because $\mathrm{SnO}_{2}$ does not have any redox couple of its own. Hence, in the absence of any mediator in the electrolyte solution $\mathrm{SnO}_{2}$ does not show any redox peak. On the other hand, the $\mathrm{CV}$ spectrum of $\mathrm{Cu}: \mathrm{SnO}_{2} / \mathrm{Pt} /$ glass electrode, clearly shows well defined redox peaks in a mediator-free PBS buffer which is attributed to valence transformation of copper from $\mathrm{Cu}^{1+}$ to $\mathrm{Cu}^{2+}$ and vice-versa, thus resulting in accelerated electron transfer. These results indicate that $\mathrm{Cu}$ is responsible for the reversible redox property in the electrode and serves as the electron transfer channel. The value of peak oxidation current obtained for $\mathrm{Cu}$ implanted $\mathrm{SnO}_{2} / \mathrm{Pt} / \mathrm{Ti} /$ glass matrix was found to be much higher in comparison to that reported for other ion implanted metal oxide matrices for biosensing such as $\mathrm{Fe}: \mathrm{ZnO}$ [16]. It may be clearly seen from inset (a) of Figure 3 that the electrode implanted at a fluence of $10^{16} \mathrm{~cm}^{-2}$ gives higher peak oxidation current $(0.72 \mathrm{~mA})$ than at lower fluence and hence chosen for further studies.

\section{Immobilization of enzyme onto the $\mathrm{Cu}_{\mathrm{SnO}} / \mathrm{Pt} / \mathrm{Ti} /$ glass electrode}

Atomic force microscopy: The AFM images showing surface morphology of the $\mathrm{Cu}$ implanted $\mathrm{SnO}_{2}$ (fluence $10^{16} \mathrm{~cm}^{-1}$ ) before and after immobilization of uricase is shown in Figure $4 \mathrm{a}$ and $4 \mathrm{~b}$, respectively. The surface morphology of the $\mathrm{Cu}$ implanted $\mathrm{SnO}_{2}$ thin 
film was rough (average roughness $\sim 10 \mathrm{~nm}$ ) with fine microstructure having uniformly distributed small size grains, and is beneficial for the efficient loading of enzyme on its surface. Upon immobilization of uricase on the surface of implanted matrix, clusters of uricase biomolecules forming a globular structure of much bigger size $(\sim 2 \mu \mathrm{m})$ are seen Figure $4 \mathrm{~b}$. This confirms the successful immobilization of enzyme (uricase) onto the surface of $\mathrm{Cu}: \mathrm{SnO}_{2} / \mathrm{Pt} / \mathrm{Ti} /$ glass electrode.

\section{FTIR studies}

The prepared $\mathrm{Cu}$ implanted $\mathrm{SnO}_{2}$ films were characterized by FTIR spectroscopy before and after immobilization of enzyme and the corresponding spectra are shown in Supplementary Figures $2 \mathrm{a}$ and $2 \mathrm{~b}$, respectively. The sharp and well defined absorption peak observed at around $606 \mathrm{~cm}^{-1}$ in Supplementary Figure 2a corresponds to the $\mathrm{SnO}_{2}$ lattice mode [17]. The absorption bands observed at around 2852, 1359 and $1094 \mathrm{~cm}^{-1}$ (Supplementary Figure 2a) can be assigned to the $-\mathrm{OH}$ groups attached directly to the surface oxygen of the $\mathrm{SnO}_{2}$ film [18]. The absorption band at $1660 \mathrm{~cm}^{-1}$ is attributed to $\mathrm{H}-\mathrm{O}-\mathrm{H}$ in-plane deformation. The interaction of the $\mathrm{O}-\mathrm{OH}$-group can be seen at 2047 and $2452 \mathrm{~cm}^{-1}$. The absorption band observed at $508 \mathrm{~cm}^{-1}$ corresponds to the vibrations related to $\mathrm{Cu}$, which confirms that the $\mathrm{Cu}$ is efficiently implanted into the $\mathrm{SnO}_{2}$ thin film matrix. Binding of the enzyme (uricase) onto the surface of $\mathrm{Cu}: \mathrm{SnO}_{2} / \mathrm{Pt} / \mathrm{Ti} /$ glass electrode is revealed by the appearance of additional absorption bands at around $1071,1175,1640,2157,2922$ and $3370 \mathrm{~cm}^{-1}$ (Supplementary Figure 2b). The sharp band at $1640 \mathrm{~cm}^{-1}$ (Supplementary Figure 2b) is associated with the carbonyl stretch (amide 1 band). The band at 1071 and $1175 \mathrm{~cm}^{-1}$ correspond to $\mathrm{C}-\mathrm{H}$ bonding of alkene and $\mathrm{C}-\mathrm{N}$ vibrations, respectively. The bands at 2157 and $2922 \mathrm{~cm}^{-1}$ corresponds to $-\mathrm{CH}$ stretching of $-\mathrm{CH}_{2}$ groups. Furthermore, a broad absorption peak at $3370 \mathrm{~cm}^{-1}$ (Supplementary Figure $2 \mathrm{~b}$ ) is related to the $\mathrm{O}-\mathrm{H}$ stretching mode. The presence of observed stretching modes confirm the effective immobilization of uricase onto the surface of $\mathrm{Cu}: \mathrm{SnO}_{2}$ thin film matrix.

\section{Electrochemical impedance spectroscopy (EIS)}

Electrochemical impedance spectroscopy (EIS) analysis has been carried out using a three-electrode cell with the $\mathrm{SnO}_{2} / \mathrm{Pt} / \mathrm{Ti} /$ glass and $\mathrm{Cu}: \mathrm{SnO}_{2} / \mathrm{Pt} / \mathrm{T} /$ glass electrodes as working electrode, platinum $(\mathrm{Pt})$ foil as counter electrode and $\mathrm{Ag} / \mathrm{AgCl}$ as reference electrode in PBS solution containing $\left[\mathrm{K}_{3} \mathrm{Fe}(\mathrm{CN})_{6}\right]^{3-14-}$ as the mediator in the frequency range $100 \mathrm{kHz}$ to $10 \mathrm{mHz}$. Supplementary Figure 3 shows the Nyquist plots obtained for (i) $\mathrm{SnO}_{2} / \mathrm{Pt} / \mathrm{Ti} /$ glass electrode, (ii) $\mathrm{Cu}: \mathrm{SnO}_{2} / \mathrm{Pt} / \mathrm{Ti} /$ glass electrode and (iii) Uricase/ $\mathrm{Cu}: \mathrm{SnO}_{2} / \mathrm{Pt} / \mathrm{Ti} /$ glass bioelectrode. The Nyquist plot includes a semicircle portion corresponding to the electron-transfer-limiting process and a linear part resulting from the diffusion-limiting step of the electrochemical process (Supplementary Figure 3). The diameter of the semicircle gives the electron-transfer resistance $\left(\mathrm{R}_{\mathrm{c}}\right)$ of the electrode-solution interface. The values of charge transfer resistance $\left(\mathrm{R}_{\mathrm{ct}}\right)$ obtained from Supplementary Figure 3 for $\mathrm{SnO}_{2} / \mathrm{Pt} / \mathrm{Ti} /$ glass, (ii) $\mathrm{Cu}: \mathrm{SnO}_{2} / \mathrm{Pt} / \mathrm{Ti} /$ glass and (iii) Uricase/ $\mathrm{Cu}: \mathrm{SnO}_{2} /$ $\mathrm{Pt} / \mathrm{Ti} /$ glass electrodes are found to be about $460 \mathrm{ohms}, 250 \mathrm{ohms}$ and $350 \mathrm{ohms}$, respectively. The value of $\mathrm{R}_{\mathrm{ct}}$ shows the electron-transfer kinetics of the redox probe at the electrode interface. Thus, the observed decrease in the value of $R_{c t}$ of the electrodes from $460 \mathrm{ohms}$ to $250 \mathrm{ohms}$, after implantation of $\mathrm{Cu}$ into $\mathrm{SnO}_{2}$ matrix (Supplementary Figure 3, curve (ii)), indicates the improved charge transfer characteristics of the implanted $\mathrm{Cu}: \mathrm{SnO}_{2}$ matrix. This is due to metallic character of the incorporated $\mathrm{Cu}$ into $\mathrm{SnO}_{2}$ matrix which provides electron conduction channel between the electrode and electrolyte. The enhancement in the $\mathrm{R}_{\mathrm{ct}}$ value to $350 \mathrm{ohms}$ for uricase/Cu:SnO $/ \mathrm{Pt} / \mathrm{Ti} /$ glass bioelectrode, Supplementary Figure 3, curve (iii) confirms the binding of bulky nonconducting macromolecules of enzyme onto the surface of $\mathrm{Cu}: \mathrm{SnO}$ matrix which provide hindrance to the conduction of charge carriers..

\section{Sensing response characteristics}

It is known that the $\mathrm{pH}$ of the electrolyte solution changes the activity of the biomolecules to a great extent. CV response of the prepared uricase $/ \mathrm{Cu}: \mathrm{SnO}_{2} / \mathrm{Pt} / \mathrm{Ti} /$ glass bio-electrode was investigated at various $\mathrm{pH}$ levels (6.0 to 8.0) of the PBS buffer and the variation of the peak oxidation current $\left(\mathrm{I}_{\mathrm{pa}}\right)$ with $\mathrm{pH}$ is shown in the inset of Figure 3 . The peak oxidation current $\left(\mathrm{I}_{\mathrm{pa}}\right)$ was found to increase with an increase in $\mathrm{pH}$ from 6.0 to 7.0 having a maximum value of $750 \mu \mathrm{A}$ and decreases thereafter with further increase in $\mathrm{pH}$. Therefore, the $\mathrm{pH}$ of the PBS solution was kept at 7.0 for amperrometric studies. The CV spectra were recorded for uricase $/ \mathrm{Cu}: \mathrm{SnO}_{2} / \mathrm{Pt} / \mathrm{Ti} /$ glass bioelectrode at varying scan rates from 100 to $600 \mathrm{mV} / \mathrm{s}$ as shown in Supplementary Figure 4 . Both the oxidation $\left(\mathrm{I}_{\mathrm{pa}}\right)$ and reduction ( $\mathrm{I}_{\mathrm{pc}}$ ) peak currents were found to increase linearly with the increase in scan rate from 100 to $600 \mathrm{mV} / \mathrm{s}$ (inset of Supplementary Figure 4). The linear relationship between the peak currents $\left(I_{p a}\right.$ or $\left.I_{p c}\right)$ and scan rate $(v)$ demonstrates that the electrochemical reaction of immobilized uricase on $\mathrm{Cu}$ implanted $\mathrm{SnO}_{2}$ electrode is a surface-controlled process. Furthermore, the redox potentials corresponding to the anodic and cathodic peak currents shift respectively towards the higher potential and lower potential with (c)

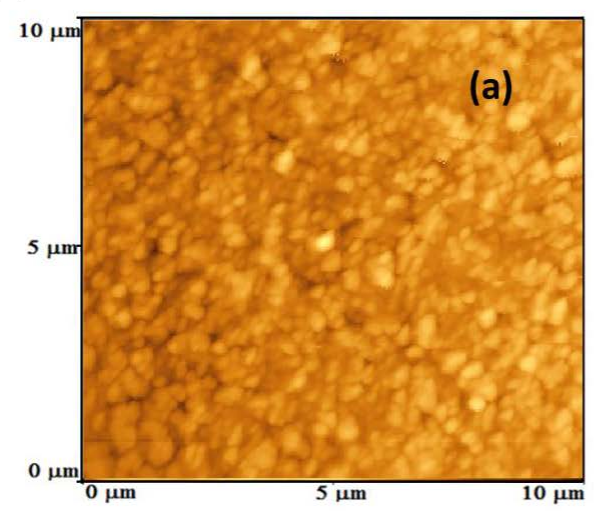

(g)

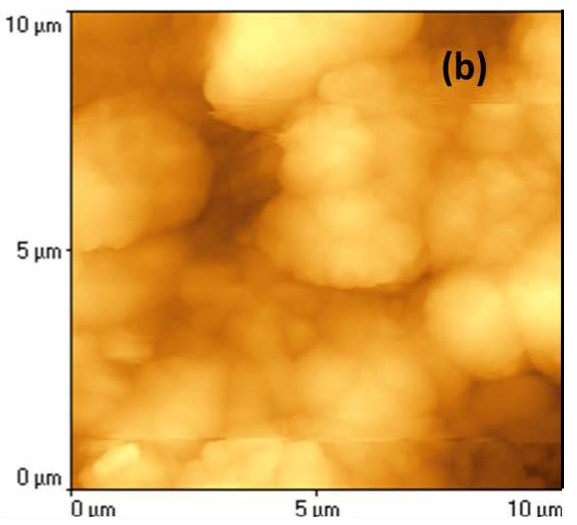

Figure 4: AFM image of the surface of $\mathrm{Cu}$ implanted $\mathrm{SnO}_{2}$ electrode at a fluence of $10^{16} \mathrm{~cm}^{-2}(\mathrm{a})$ before and (b) after uricase immobilization. 
increase in scan rate (Supplementary Figure 4). The observed variation in redox potential confirms that the reaction is quasi-reversible.

The surface concentration of ionic species per unit area for uricase/ $\mathrm{Cu}$ implanted $\mathrm{SnO}_{2} / \mathrm{Pt} / \mathrm{Ti} /$ glass bio-electrode is estimated using Brown-Anson model. The estimated value of surface concentration of electroactive uricase on the surface of the prepared bioelectrode is found to be about $5.42 \times 10^{-5} \mathrm{~mole} / \mathrm{cm}^{2}$ which is greater in comparison to the corresponding values reported by various workers for uric acid biosensors using other metal oxide matrices $[5,6]$. The high surface concentration obtained in the present work confirms that the prepared bioelectrode offers high enzyme loading. This is attributed to the preparation of implanted matrix with desired rough surface morphology. The high enzyme loading is expected to provide the enhanced sensitivity of the developed biosensor. The results indicate that $\mathrm{Cu}$ implantation is effective not only in enhancing the electron communication property of $\mathrm{SnO}_{2}$ matrix, but also in increasing the electroactive surface area of the matrix.

The sensing response of the bioelectrode (uricase/Cu:SnO$/ 2 \mathrm{Pt} /$ $\mathrm{Ti} /$ glass) has been obtained using the $\mathrm{CV}$ spectra recorded with increasing concentration of uric acid in the PBS electrolyte (Figure 5). The physiological range of uric acid in human serum is between 0.13 to $0.46 \mathrm{mM}$. Thus, the concentration of uric acid (analyte) was varied from 0.05 to $1.0 \mathrm{mM}$ in the electrolyte solution. It may be observed from Supplementary Figure 5 that the oxidation peak current increases linearly from $0.17 \mathrm{~mA}$ to $1.09 \mathrm{~mA}$ with an increase in uric acid concentration from 0.05 to $1.0 \mathrm{mM}$. The $\mathrm{CV}$ responses were used to draw a calibration curve for the uricase $/ \mathrm{Cu}: \mathrm{SnO}_{2} / \mathrm{Pt} / \mathrm{Ti} /$ glass electrode on interaction with the varying concentration of uric acid as shown in the inset (a) of Figure 5. It may be clearly seen from the calibration curve that the uricase/Cu:SnO$/ \mathrm{Pt} /$ glass electrode exhibits good linearity for the sensing of uric acid in a wide range from $0.05 \mathrm{mM}$ to $1.00 \mathrm{mM}$ with a correlation coefficient of 0.99 . Sensitivity of the uricase/Cu: $\mathrm{SnO}_{2} /$ $\mathrm{Pt} /$ glass bioelectrode is calculated from the slope of the calibration curve and is found to be about $0.93 \mathrm{~mA} / \mathrm{mM}$ with a low limit of detection (LOD) of $0.06 \mathrm{mM}$. Sensitivity of the bioelectrode towards uric acid is found to be higher compared to the corresponding values reported by various workers for other metal oxide matrices (Table 1).
Furthermore, the bioelectrode is found to exhibit fast response time of about 4 seconds due to the fast electron transfer between the active sites of enzyme and electrode. The affinity of uricase immobilized on the surface of the $\mathrm{Cu}: \mathrm{SnO}_{2}$ film towards uric acid is determined from the value of Michaelis-Menten kinetic parameter $\left(\mathrm{K}_{\mathrm{m}}\right)$ estimated from Hanes plot as shown in the inset (b) of Figure 5. The estimated value of $\mathrm{K}_{\mathrm{m}}$ is found to be about $0.12 \mathrm{mM}$ which is lower than values reported by other workers for uric acid biosensors (Table 1). The low value of $\mathrm{K}_{\mathrm{m}}$ indicates that the immobilized uricase in the present work has high affinity towards uric acid.

To carry out the photometric enzyme assay, the bioelectrode was dipped in $3 \mathrm{~mL}$ PBS solution containing $20 \mu \mathrm{L}$ horseradish peroxidise (HRP), $20 \mu \mathrm{L}$ o-dianisidine dye and $100 \mu \mathrm{L}$ of analyte (uric acid) in varying concentration. The difference between the values of initial absorbance and final absorbance at $500 \mathrm{~nm}$ after 2 min incubation of the bioelectrode was recorded and plotted in Supplementary Figure 5 as a function of uric acid concentration. The enzyme activity is found to increase with an increase in the concentration of uric acid upto $0.7 \mathrm{mM}$ and thereafter shows a saturation effect (Supplementary Figure 5). The amount of bound enzyme on the surface of electrode is determined from the apparent enzyme activity $\left(a_{e n z}^{a p p}\right)$ calculated using the equation:

$$
\left(a_{e n z}^{a p p}\right)\left(U c m^{-2}\right)=\frac{A V}{\varepsilon t s}
$$

Where $A$ is the difference in absorbance before and after incubation, $V$ is the total volume $\left(=3.17 \mathrm{~cm}^{3}\right), \varepsilon$ is the millimolar extinction coefficient for o-dianisidine (7.5 for o-dianisidine at $500 \mathrm{~nm}), \mathrm{t}$ is the reaction time (2 mins.), and $\mathrm{s}$ is the surface area of the electrode (1.0 $\left.\times 1.0 \mathrm{~cm}^{2}\right)$. The value of apparent enzyme activity of the immobilized uricase on the $\mathrm{Cu}: \mathrm{SnO}_{2} / \mathrm{Pt} / \mathrm{Ti} /$ glass electrode is about $5.01 \times 10^{-2}$ unit/ $\mathrm{cm}^{2}$. This value is much higher than that obtained by other workers indicating that our bioelectrode provides a better platform and hence more units of uricase are actively working per unit electrode surface area $[6,19,7]$.

The selectivity of our bioelectrode is studied by recording the value of peak oxidation current in $\mathrm{CV}$ response on addition of

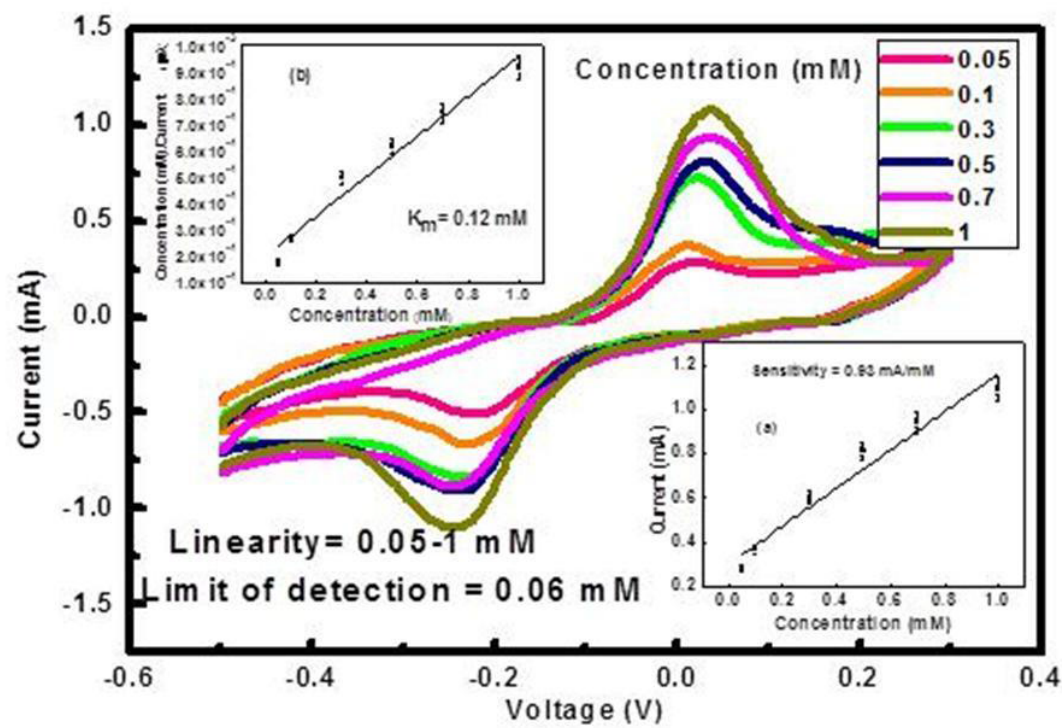

Figure 5: Amperrometric response of uricase/Cu: $\mathrm{SnO}_{2} / \mathrm{Pt} / \mathrm{Ti} / \mathrm{glass}$ bioelectrode as a function of uric acid concentration $(0.05$ to $1.0 \mathrm{mM})$. Inset (a) gives the variation in peak oxidation current with uric acid concentration and (b) Hanes plot. 


\begin{tabular}{|c|c|c|c|c|c|c|c|}
\hline \multirow{2}{*}{$\begin{array}{c}\text { Real } \\
\text { Sample } \\
\text { (Serum) }\end{array}$} & \multicolumn{2}{|c|}{ Concentration of uric acid measured (mM) } & \multirow{2}{*}{$\begin{array}{l}\text { R.S.D. of developed } \\
\text { biosensor }(n=5)(\%)\end{array}$} & \multirow{2}{*}{$\begin{array}{l}\text { Spike } \\
(\mathrm{mM})\end{array}$} & \multirow{2}{*}{$\begin{array}{l}\text { Concentration } \\
\text { of uric acid } \\
\text { detected (mM) }\end{array}$} & \multirow{2}{*}{$\begin{array}{l}\text { Recovery } \\
(\%)\end{array}$} & \multirow{2}{*}{$\begin{array}{l}\text { R.S.D. of developed } \\
\text { biosensor }(n=5)(\%)\end{array}$} \\
\hline & $\begin{array}{l}\text { Uricase } / \mathrm{Cu} / \mathrm{SnO}_{2} / \mathrm{Pt} / \mathrm{Ti} / \\
\text { glass biosensor }\end{array}$ & $\begin{array}{l}\text { Spectrophotometric } \\
\text { method }\end{array}$ & & & & & \\
\hline 1 & 0.312 & 0.319 & 1.3 & 0.5 & 0.820 & 101.6 & 1.2 \\
\hline 2 & 0.235 & 0.243 & 1.5 & 0.5 & 0.730 & 99 & 1.1 \\
\hline 3 & 0.672 & 0.676 & 2.1 & 0.5 & 1.180 & 101.6 & 1.9 \\
\hline 4 & 0.483 & 0.489 & 2.5 & 0.5 & 0.97 & 97.4 & 2.1 \\
\hline 5 & 0.849 & 0.837 & 1.8 & 0.5 & 1.355 & 101.2 & 1.6 \\
\hline 6 & 0.781 & 0.773 & 1.2 & 0.5 & 1.3 & 103.8 & 1.4 \\
\hline 7 & 0.899 & 0.901 & 2.9 & 0.5 & 1.41 & 102.2 & 2.7 \\
\hline 8 & 0.553 & 0.558 & 1.3 & 0.5 & 1.0 & 89.4 & 1.1 \\
\hline 9 & 0.581 & 0.590 & 2.3 & 0.5 & 1.13 & 109.8 & 2.0 \\
\hline 10 & 0.612 & 0.608 & 1.6 & 0.5 & 1.11 & 99.6 & 1.3 \\
\hline
\end{tabular}

Table 2: Determination and recovery of uric acid in human serum samples using the repared uricase/ $\mathrm{Cu}_{\mathrm{S}} \mathrm{SnO}_{2} / \mathrm{Pt} / \mathrm{Ti} / \mathrm{glass}$ biosensor.

normal concentration of various interferents possible in the human serum such as glucose $(5.6 \mathrm{mM})$, cholesterol $(5 \mathrm{mM})$, urea $(1 \mathrm{mM})$, ascorbic acid $(0.1 \mathrm{mM})$ and dopamine $(0.1 \mathrm{mM})$ along with the normal concentration of uric acid $(0.3 \mathrm{mM})$, and the obtained results are shown in inset of Supplementary Figure 5. The insignificant change in value of $I_{p a}$ was observed with all interferents with a maximum interference of $2.1 \%$ (inset of Supplementary Figure 5). It may be inferred that the bioelectrode is highly selective towards the uric acid and hence the sensing response is highly reliable. The shelf life studies of the bioelectrode shows that it retains more than $90 \%$ of activity even after 20 weeks as shown in Supplementary Figure 6. The enhanced sensing response characteristics are attributed to the preparation of a highly stable and biocompatible $\mathrm{Cu}$ implanted $\mathrm{SnO}_{2}$ thin film matrix in the present study [20-28].

\section{Real samples analysis}

The prepared uricase/Cu:SnO$/ 2$ Pt/glass biosensor has been exploited for the analysis of uric acid in the real biological fluid, 10 human sera samples were analyzed and the \% recovery and precision were calculated for spiked samples. After the addition of the sera samples in the electrolyte solution, the peak oxidation current values have been noted from the CV measurements. Uric acid concentration in serum was then extrapolated from the standard calibration curve between uric acid concentration (mM) and current (inset of Figure 5). Electrochemical sensing technique in the present work has been used to corroborate results obtained by commercial spectrophotometric method in the clinical laboratory. To validate Accuracy of the prepared electrode has been validated by determining the content of uric acid in serum samples and has been compared with that measured by commercial spectrophotometric method in the clinical laboratory. Table 2 summarizes the results obtained during the present investigation. The results indicate that the uric acid analysis in sera with the developed biosensor agrees well with the spectrophotometric data. Recovery tests were also performed in order to demonstrate the accuracy and precision of the prepared biosensor by adding a known concentration of uric acid $(0.50 \mathrm{mM})$ in the already tested serum samples and then estimating the concentration of added uric acid (Table 2). The performed recovery tests confirm that the fabricated biosensor is accurate and precise. The performance of the prepared biosensor system is comparable with the commercially accepted methods. For in-vivo application of the biosensor in clinical practice, the requirements of biocompatibility, linearity, sensitivity, specificity, accuracy and long-term stability were very well fulfilled by uricase/ $\mathrm{Cu}: \mathrm{SnO}_{2} / \mathrm{Pt} / \mathrm{Ti} /$ glass based biosensor.

\section{Conclusion}

A novel reagentless uric acid biosensor based on efficient transfer of electron from the immobilized enzyme onto the electrode via implanted $\mathrm{Cu}$ in $\mathrm{SnO}_{2}$ matrix is developed. The uricase/Cu:SnO${ }_{2} / \mathrm{Pt} /$ glass bioelectrode exhibits enhanced sensitivity $(0.93 \mathrm{~mA} / \mathrm{mM})$ with good linearity over a wide detection range $(0.05$ to $1.0 \mathrm{mM})$ in the absence of any external mediator in the PBS solution. The low $\mathrm{K}_{\mathrm{m}}$ value $(0.12 \mathrm{mM})$ obtained for the bioelectrode indicates high affinity of uricase immobilized on the surface of $\mathrm{Cu}: \mathrm{SnO}_{2}$ matrix towards uric acid. The apparent enzyme activity is about $5.01 \times 10^{-2}$ unit $/ \mathrm{cm}^{2}$. The biosensor exhibits very high stability with a shelf-life of about 20 weeks. The observed results confirmed that $\mathrm{Cu}$ implanted $\mathrm{SnO}_{2}$ matrix is attractive for realization of efficient uric acid biosensor with enhanced sensitivity, good selectivity and high stability.

\section{Acknowledgements}

Authors are thankful to Professor C Jagadish and Dr Hoe Tan, Australian National University, Australia for carrying out the implantation of copper for present work. Authors are thankful to Department of Science and Technology (DST), Govt. of India for the financial support to carry out the proposed work. One of the authors (KA) acknowledges CSIR for fellowship.

\section{References}

1. Jindal K, Tomar M, Gupta V (2012) CuO thin film based uric acid biosensor with enhanced response characteristics. Biosensors and Bioelectronics 38: 11-18.

2. Tyagi M, Tomar M, Gupta V (2013) NiO Nanoparticle-based Urea Biosensor Biosensors and Bioelectronics 41: 110-115.

3. Ahuja T, Kumar R, Tanwar VK, Sharma V, Singh N, et al. (2010) An amperometric uricacid biosensor based on Bis[sulfosuccinimidyl] suberate crosslinker/3-aminopropyltriethoxysilane surface modified ITO glass electrode. Thin Solid Films 519: 1128-1134.

4. Wang X, Hagiwara T, Uchiyama S (2007) Immobilization of uricase within polystyrene using polymaleimidostyrene as a stabilizer and its application to uric acid sensor. Analytica Chimica Acta 587: 41-46.

5. Wang $Y$, Hasebe $Y(2012)$ Uricase-adsorbed carbon-felt reactor coupled with a peroxidase-modified carbon-felt-based $\mathrm{H}_{2} \mathrm{O}_{2}$ detector for highly sensitive amperometric flow determination of uric acid. Journal of Pharmaceutical and Biomedical Analysis 57: 125- 132.

6. Liu X, Peng Y, Qua X, Ai S, Han R, et al. (2011) Multi-walled carbon nanotubechitosan/poly(amidoamine)/DNA nanocomposite modified gold electrode for determination of dopamine and uric acid under coexistence of ascorbic acid. Journal of Electroanalytical Chemistry 654: 72-78.

7. Arora K, Sumanaa G, Saxena V, Gupta RK, Gupta SK, et al. (2007) Improved performance of polyaniline-uricase biosensor. Analytica Chimica Acta 594: 17-23.

8. Zen JM, Lai YY, Yang HH, Kumar AS (2002) Multianalyte sensor for the simultaneous determination of hypoxanthine, xanthine and uric acid based on a preanodized nontronite-coated screen-printed electrode. Sensors and Actuators B 84: 237-244. 
Citation: Arora K, Tomar M, Gupta V (2017) Modified Tin Oxide Based Bioelectrode for Reagentless Detection of Uric Acid. J Biosens Bioelectron 8: 246. doi: $10.4172 / 2155-6210.1000246$

Page 8 of 8

9. Zhang FF, Li X, Li CX, Li XH, Wan Q, et al. (2005) $\mathrm{SnO}_{2}$ ref Assay for uric acid level in rat striatum by a reagentless biosensor based on functionalized multiwall carbon nanotubes with tin oxide. Anal. Bioanal. Chem 382: 1368-1373.

10. Saha S, GuptaV, Sreenivas K, Tan HH, Jagadish C (2010) Third generation biosensing matrix based on Fe-implanted $\mathrm{ZnO}$ thin film. Applied Physics Letters 97: 133704

11. Saha S, Tomar M, Gupta V (2012) Fe doped ZnO thin film for mediator-less biosensing application. J Appl Phys 111: 102804.

12. Liu C, Mensching B, Zeitler M, Volz K, Rauschenbach B (1998) Ion implantation in $\mathrm{GaN}$ at liquid-nitrogen temperature: Structural characteristics and amorphization. Physical Review B 57: 2530-2535.

13. Janjua SA, Shah SH, Mehmood A, Zahid F, Mehmood M, et al. (2010) Ion Implantation into Aluminum and Copper by Beam of Carbon Nanoparticles from Regenerative Sooting Discharges. Nucl. Instrum. Methods Phys. Res. B 268: 2785-2789.

14. Li S, Xia J, Liu C, Cao W, Hu J, et al. (2009) Direct electrochemistry of cytochrome $\mathrm{c}$ at a novel gold nanoparticles-attached ions implantation-modified indium tin oxide electrode. J Electroanal Chem 633: 273-278.

15. Sharma A, Tomar M, GuptaV (2011) $\mathrm{SnO}_{2}$ thin film sensor with enhanced response for $\mathrm{NO}_{2}$ gas at lower temperatures. Sensors and Actuators B 156: 743-752.

16. Saha S, GuptaV (2011) Al and Fe co-doped transparent conducting ZnO thin film for mediator-less biosensing application. AIP Advances 1: 042112

17. Bentley FF, Smithson LD, Rozek AL (1968) Infrared Spectra and Characteristic Frequencies. Interscience Publishers, New York, London and Sydney.

18. Milligan DE, Jacox ME (1963) Infrared spectroscopic evidence for the species $\mathrm{HO}_{2}$. J Chem Phys 38: 2627-2632.

19. Nathaly CM, Osvaldo N, Oliveira J, Caseli L (2012) Immbolization of uricase enzyme in Langmuir and Langmuir-Blodgett films of fatty acids: Possible use as a uric acid sensor. J Colloid Interface Sci 373: 69-74.

20. Ali USM, Alvia NH, Ibupoto Z, Nur O, Willander M, et al. (2011) Selective potentiometric determination of uric acid with uricase immobilized on $\mathrm{ZnO}$ nanowires. Sensors and Actuators B 152: 241-247.

21. Schrenkhammer $P$, Wolfbeis OS (2008) Fully reversible optical biosensors for uric acid using oxygen transduction. Biosensors and Bioelectronics 24: $994-$ 999.

22. Miland E, Miranda AJ (1996) Poly(o-aminophenol)-modified bienzyme carbon paste electrode for the detection of uric acid. Talanta 43: 785796

23. Chauhan N, Pundir CS (2011) An amperometric uric acid biosensor based on multiwalled carbon nanotube-gold nanoparticle composite. Analytical Biochemistry 413: 97-103.

24. Revin SB, John SA (2012) Selective determination of I-tyrosine in the presence of ascorbic and uric acids at physiological $\mathrm{pH}$ using the electropolymerized film of 3-amino-5-mercapto-1,2,4-triazole. Sensors and Actuators B 161: 10591066.

25. Arora J, Nandwani S, Bhambi M, Pundir CS (2009) Fabrication of dissolved $O_{2}$ metric uric acid biosensor using uricase epoxy resin biocomposite membrane. Analytica Chimica Acta 9: 647,195-201.

26. Luo YC, Doa JS, Liu CC (2006) An amperometric uric acid biosensor based on modified Ir-C electrode. Biosensors and Bioelectronics 22: 482-488.

27. Rawal R, Chawla S, Chauhan N, Dahiya T, Pundir CS (2012) Construction of amperometric uric acid biosensor based on uricase immobilized on PBNPS/CMWCNT/PANI/Au composite. International Journal of Biological Macromolecules 50: 112-118.

28. Behera S, Raj RC (2007) Self-assembled monolayers of thio-substituted nucleobases on gold electrode for the electroanalysis of $\mathrm{NADH}$, ethanol and uric acid. Sensors and Actuators B 128: 31-38. 